\title{
Financial Ratios (Accounting Ratios) and Survival of Microfinance Institutions in Ghana
}

\author{
Sarkodie EE ${ }^{1 *}$, Addai I ${ }^{1}$ and Asiedu DK $^{2}$ \\ ${ }^{1}$ Department of Accounting Studies Education, College of Technology Education, Kumasi, Ghana \\ ${ }^{2}$ University of Education, Winneba, College of Technology Education, Kumasi, Ghana
}

\begin{abstract}
Accounting Ratio is a way of expressing the relationship between one accounting result and another, which is intended to provide a useful comparison. Accounting ratios assist in measuring the efficiency and profitability of a company based on its financial reports. Accounting ratios are important for financial decision making irrespective of the size of the institution. The Bank of Ghana has the constitutional mandate to oversee the activities of all financial institutions in Ghana including the Microfinance institutions. This core mandate of Bank of Ghana is basically guided by the use of accounting ratios. The ratios per their style have the power to determine the risk exposure of financial institutions. Over the past five years the Ghanaian economy has witnessed the collapse of certain microfinance institutions that the public assumed to be highly visible in the financial market. The study therefore provided a logistic regression model with 117 observations to determine whether accounting ratios have the power to predict the fortunes of microfinance institutions in Ghana. An increase in the current ratio reduces the log-odds of a firm's survival by -1.461987 . An increase in the acid test ratio improves the log-odds of survival by 6.847345 . An increase in the debt equity ratio increases the chances of survival of a firm by 1.055941 . Current ratio and acid test ratio were statistically significant at 10 percent whilst debt equity ratio was statistically significant at 5 percent. The study implies that microfinance institutions should be mindful of the current ratio, acid test ratio and the debt to equity ratio.
\end{abstract}

Keywords: Financial ratios; Stock; Business; Microfinance; Enterprise

\section{Introduction}

A financial ratio or accounting ratio is a relative magnitude of two selected numerical values taken from an enterprise's financial statements (wiki). Accounting Ratio is a way of expressing the relationship between one accounting result and another, which is intended to provide a useful comparison. Accounting ratios assist in measuring the efficiency and profitability of a company based on its financial reports. Accounting ratios form the basis of fundamental analysis. An accounting ratio compares two aspects of a financial statement, such as the relationship (or ratio) of current assets to current liabilities. The ratios can be used to evaluate the financial condition of a company, including the company's strengths and weaknesses (Investopedia) [1].

Financial ratios quantify many aspects of a business and are an integral part of the financial statement analysis. Financial ratios are categorized according to the financial aspect of the business which the ratio measures. Liquidity ratios measure the availability of cash to pay debt. Activity ratios measure how quickly a firm converts non-cash assets to cash assets. Debt ratios measure the firm's ability to repay long-term debt. Profitability ratios measure the firm's use of its assets and control of its expenses to generate an acceptable rate of return. Market ratios measure investor response to owning a company's stock and also the cost of issuing stock. These are concerned with the return on investment for shareholders, and with the relationship between return and the value of an investment in company's shares. Financial ratios allow for comparisons;

1. Between companies

2. Between industries

3. Between different time periods for one company

4. Between a single company and its industry average

Ratios generally are not useful unless they are benchmarked against something else, like past performance or another company. Thus, the ratios of firms in different industries, which face different risks, capital requirements, and competition, are usually hard to compare.

The objective of this study was to find out whether accounting ratios have the capacity to tell the fortunes of microfinance institutions. The research questions that were asked included:

1. Does Current Ratio predict survival?

2. Does Quick Ratio predict survival?

3. Does Debt to Equity Ratio predict survival?

This study will contribute to microfinance management and policy making in the financial market at large.

\section{Literature Review}

Naser [1] conducted a study to find out if Financial Ratios Reliably Measure the Performance of Banks in Bahrain. The study covered the calculation of important financial ratios of major financial institutions in Bahrain as well as comparing their performance in the context of the global financial crisis. It also compared ratios of conventional banks with Islamic financial institutions in Bahrain. These ratios defined profitability, financial performance, size and type of banks. The result of the analysis of ratios for measuring financial performance showed

${ }^{*}$ Corresponding author: Sarkodie EE, University of Education, Winneba, College of Technology Education, Department of Accounting Studies Education, Kumasi, Ghana, Tel: 03323-22139; E-mail: effahsarkodie@yahoo.com

Received August 07, 2015; Accepted September 21, 2015; Published October 15,2015

Citation: Sarkodie EE, Addai I, Asiedu DK (2015) Financial Ratios (Accounting Ratios) and Survival of Microfinance Institutions in Ghana. J Bus Fin Aff 4: 151. doi:10.4172/2167-0234.1000151

Copyright: (c) 2015 Sarkodie EE, et al. This is an open-access article distributed under the terms of the Creative Commons Attribution License, which permits unrestricted use, distribution, and reproduction in any medium, provided the original author and source are credited. 
that there is corporate excellence in asset management and value equity shares. The study also recommended that the analysis could be used as a basis for preventative actions for future bankruptcy and market risk.

Lenders often rely on ratio analysis because it allows them to see how one's business is doing and how compare it compares to other businesses which they have loaned money to. The potential loan creditor also requires information about security that the Ratio Analysis can be provided [2].

Ratio analysis is a useful tool for business owners as well. It measures the health of the business whether it is a bank or a multinational corporation. It helps to measure the performance of the business, to diagnose potential problems and to see how well it is doing over time.

Finch [3] stated that financial ratios are one of the most common tools of managerial decision making. A ratio is to compare one number to another-mathematically, a simple division problem. Financial ratios involve the comparison of various figures from the financial statements in order to gain information about a company's performance. It is the interpretation, rather than the calculation, that makes financial ratios a useful tool for business managers. The future decisions can be evaluated in terms of measuring the behavior of the firm value, given a decision to be analyzed. However, examining historical financial statements analysis has the limitations in reaching the optimal financial decisions. Ratios may serve as indicators, clues, or red flags regarding not worthy relationships between variables used to measure the firm's performance in terms of profitability, asset utilization, liquidity, leverage, or market valuation [4].

Singh [5] in his study identified commonly used ratios in the lodging industry and discovered their importance for lodging financial executives. In his point of view, financial ratios have always been a valuable tool for lodging industry managers. Ratios allow the user to summarize and analyze related data to provide meaningful information for making decisions $[6,7]$.

\section{Problem Statement}

Accounting ratios are important for financial decision making irrespective of the size of the institution. The Bank of Ghana has the constitutional mandate to oversee the activities of all financial institutions in Ghana including the Microfinance institutions. This core mandate of Bank of Ghana is basically guided by the use of accounting ratios. The ratios per their style have the power to determine the risk exposure of financial institutions [1]. Bank of Ghana is indeed noted for strict adherence to these accounting ratios. However, over the past five years the Ghanaian economy has witnessed the collapse of many microfinance institutions that the public assumed to be highly visible in the financial market. Some of these collapsed institutions include Noble Dream Microfinance, Above All Financial Services and KAD Microfinance. This study therefore tried to calculate some of these accounting ratios of microfinance institutions in Ghana including those that have collapsed and those that are still in operation. The study thereafter provided a logistic regression model to determine whether accounting ratios have the power to predict the fortunes of microfinance institutions in Ghana.

\section{Methodology}

\section{Model specification}

This study adopted Logistic regression modeling technique. The choice of this methodology is based on the fact that the regress and of the model is binary. The logistic regression is specified as

$$
\ln \left[\mathrm{P}_{\mathrm{i}} /\left(1-\mathrm{P}_{\mathrm{i}}\right)\right]=\chi_{0}+\chi_{1} \mathrm{cr}+\chi_{2} \operatorname{atr}+\chi_{3} \operatorname{der}++\mu
$$

Where: $c r=$ Current ratio , atr $=$ Acid Test Ratio, der=Debt Equity Ratio, $\mu=$ Error term, $\lambda_{0} . \chi_{3}=$ The parameters to be estimated. $\left[\mathrm{P}_{\mathrm{i}} /\left(1-\mathrm{P}_{\mathrm{i}}\right)\right]$ $=$ The Odds of survival of Microfinance institutions.

\section{Definition of variables}

Current Ratio is a relationship of current assets to current liabilities. Current Assets are the assets that are either in the firm of cash or cash equivalents or can be converted into cash or cash equivalents in a short time (say, within a year's time) and Current Liabilities are repayable in a short time. It is calculated as follows:

$$
\text { Current Ratio }=\frac{\text { current assets }}{\text { current liabilities }}
$$

The objective of calculating Current Ratio is to assess the ability of the enterprise to meet its short-term liabilities promptly. It shows the number of times the current assets can be converted into cash to meet current liabilities. As a normal rule current assets should be twice the current liabilities. Low ratio indicates inadequacy of the enterprise to meet its current liabilities and inadequate working Capital. High Ratio is an indication of inefficient utilization of funds. An enterprise should have a reasonable current ratio. Although there is no hard and fast rule yet a current ratio of $2: 1$ is preferable.

Acid Test Ratio: is a relationship of liquid assets with current liabilities and is computed to assess the short- term liquidity of the enterprise in its correct form.

This is calculated as follows:

$$
\text { Acid Test Ratio }=\frac{\text { current assets }}{\text { current liabilities }}
$$

Quick assets $=$ Current assets $-($ stock + Prepaid Expenses $)$ Liquid assets are the assets, which are either in the form of cash or cash equivalent or can be converted into cash within a very short period. Liquid assets include cash, bills receivable, marketable securities and debtors (excluding bad and Doubtful debts), etc. Stock is excluded from liquid assets as it may take some time before it is converted into cash. Similarly prepaid expenses do not provide cash at all and are thus excluded from liquid assets. A quick ratio of 1:1 is usually considered favorable, since for every rupee of current liabilities, there is a rupee of current assets. A high Acid Test ratio compared to current ratio may indicate under stocking while a low liquidity ratio while a low Acid Test ratio indicated overstocking.

Debt-Equity Ratio- It is computed to ascertain the soundness of the long-term financial position of the firm. This ratio expresses the relationship between debt (external equities) and the equity (internal equities) Debt means long term loans, i.e., debentures, long-term loans from financial institution. Equity means shareholders' funds, i.e., preference share capital, equity share capital, reserves less losses and fictitious assets like preliminary expenses. The ratio is ascertained as follows:

$$
\text { Debt }- \text { equity Ratio }=\frac{\text { Debt }(\text { long }- \text { term loans })}{\text { Equity }(\text { shareholders' Funds })}
$$

Higher Ratio indicates risky financial position while lower ratio indicates safe financial position. Acceptable Debt-Equity Ratio is 2:1 which means debt can be twice the equity. This ratio is significant to 


\begin{tabular}{|c|c|c|c|c|c|}
\hline Survive & Coef. & Std. Err. & $\mathbf{z}$ & P>|z| & [95\% Conf. Interval] \\
\hline cr & $-1.461987^{*}$ & .7994525 & -1.83 & 0.067 & 0.077 \\
\hline acr & $6.847345^{*}$ & 3.87012 & 1.77 & 0.028885 & -.7379499 \\
\hline der & $1.055941^{* *}$ & .3075388 & 3.43 & 14.43264 & .4531757 \\
\hline cons & -.9088469 & .6503588 & -1.40 & 0.162 & -2.183527 \\
\hline
\end{tabular}

*Significant at 10 percent, ** significant at 5 percent.

Number of observation $=117$, Log likelihood chi square $=35.18$ Prob $>$ chi $^{2}=0.0000$

$\mathrm{cr}=$ current ratio, atr= acid test ratio, der= debt-equity ratio, _cons=constant term

Table 1: Logistic Regression Results.

access the soundness of long -term financial position. It also indicates the extent to which firm depends upon outsiders for its existence. It portrays the proportion of total funds acquired by a firm by way of loans.

\section{Data, population and sample}

The study relied purely on cross sectional and secondary data collected from one hundred and seventeen microfinance institutions (117) in Ghana. The secondary source is from the annual audited accounts of these microfinance institutions. The population in this study includes all microfinance institutions in Ghana.

\section{Results and Discussion}

The table below is a logistic regression results which indicates that one hundred and seventeen microfinance institutions were used and there was no missing value. The log likelihood ratio of 35.18 with a chi square of 0.0000 is an indication that the model as whole fits better than a model with no predictors.

Number of observation $=117, \log$ likelihood chi square $=35.18$ Prob $>$ chi $^{2}=0.0000$

$c r=$ current ratio, atr $=$ acid test ratio, der $=$ debt-equity ratio, cons $=$ constant term

An increase in the current ratio reduces the log-odds of a firm's survival by -1.461987 . That is as the firms' current assets increases too much relative to their current liabilities they stand the risk of collapsing. In other words, microfinance institutions may not be able to meet their liabilities if they create huge loans, which are usually a greater percentage of their current assets. Besides the current ratio proved statistically significant at 10 percent error level. This indeed, emphasizes that the variable is scientifically a true determinant of the log-odds of survival.

An increase in the acid test ratio improves the log-odds of survival by 6.847345 . That is if microfinance institutions put much of their resources into very liquid assets then there is a higher possibility of its survival. This stems from the fact that microfinance institutions can easily lay hands on these liquid assets to settle their current liabilities. Therefore, to avoid risk of collapsing microfinance institutions must put resources into liquid assets. It is moreover, observed that, the acid test ratio is statistically significant at 10 percent error level.

An increase in the debt-equity ratio also enhances the log-odds of a firm's survival. From the Table 1 an increase in the debt equity ratio increases the chances of survival of a firm by 1.055941 . This means that if the microfinance institution is able to access long term loans from other financial institutions, then it will enhance the firms chances of survival. Moreover, the debt-equity ratio is statistically significant at 5 percent error level.

\section{Implications of the Study}

The study implies that microfinance institutions should be mindful of the current ratio, acid test ratio and the debt to equity ratio.

\section{Summary and Recommendations}

Microfinance institutions may have at the heart to make profit by way of giving out several loans. However, increasing loans does not necessarily increase profit since the business can collapse through the loans giving. It is advised per the findings of this study that short term loans to customers would be of great advantage to the microfinance institutions. Also, microfinance institutions ability to invite long term loans from other financial institutions could be of great help to the microfinance institutions. This is because increasing long term loan accessibility can improve their chances of survival. In this regard an alliance of microfinance institutions would help form syndicate which can aid the assessment of long term loans from banks. Frequent monitoring of the microfinance institutions ratios would help to prevent collapsing.

\section{References}

1. Najjar NJ (2013) Can Financial Ratios Reliably Measure the Performance of Banks in Bahrain? Int J Eco Financ 5: 3.

2. Lambert RA, Larcker DF (1987) An analysis of the use of accounting and market measures of performance in executive compensation contracts, $J$ Accont Res 2: 85-125.

3. Finch H (2005) Financial Ratios. Reference for business.

4. Murthy SRY (2004) Financial Ratios of Major Commercial Banks.

5. Ward S (2003) Is Your Business Sick? Give Your Business a Health Checkup with These Three Ratios.

6. Lang M, Maffett M, Owens E (2010) Earnings comovement and accounting comparability: The effects of mandatory IFRS adoption', Working paper, UNCChapel Hill.

7. Lynch RM, Willamson RW (1983) Accounting for Management. New York: McGraw-Hill. 